MARCIN POLAKOWSKI

Wydział Humanistyczny UMK

\title{
Źródła filozofii politycznej Hobbesa w ujęciu Michaela Oakeshotta
}

T homas Hobbes zajmuje szczególne miejsce w intelektualnych poszukiwaniach Michaela Oakeshotta. Jeśli mierzyć płodność intelektualną autora liczbą napisanych przez niego dzieł, wówczas Oakeshott nie może równać się z innymi znanymi postaciami XX-wiecznej filozofii politycznej. A jednak już na poziomie enumeratywnego wyliczenia tekstów autorstwa Oakeshotta poświęconych Hobbesowi, wzbudza nasze zainteresowanie spora uwaga, jaką autor O postępowaniu człowieka poświęca właśnie „mędrcowi z Malmesbury”.

Zainteresowanie Hobbesem u Oakeshotta zaczyna się, gdy dzieło owego wczesnowożytnego myśliciela spotyka się z nową falą zaciekawienia nie tylko w Anglii, lecz również na kontynencie. Wcześniej, z uwagi na dominację heglizmu i idealizmu w filozofii europejskiej, było ono bowiem postrzegane jako niemądre, nieatrakcyjne i niespójne, by nie rzec niedorzeczne ${ }^{1}$. Warto więc odnotować, że dopiero w 1929 roku odbywa się w Oksfordzie słynne międzynarodowe spotkanie zawiązujące społeczność badaczy eksplorujących dziedzictwo tego XVII-wiecznego filozofia ${ }^{2}$. Wówczas też spotyka on się z uwagą myślicieli, zajmujących się namysłem nad polityką. W połowie lat 30. Leo Strauss kończy swoją pracę Hobbes' politische Wissenschaft in ihrer

M. Oakeshott, Leo Strauss o Hobbesie, przeł. M. Polakowski, „Dialogi Polityczne” 2009, nr 12, S. 85 .

Por. M. Oakeshott, Thomas Hobbes, [w:] tenże, The Concept of Philosophical Jurisprudence: Essays and Reviews 1926-1951, Exeter 2007, s. 110. 
Genesis ${ }^{3}$, zaś kilka lat później Carl Schmitt publikuje Der Leviathan in der Staatslehre des Thomas Hobbes ${ }^{4}$. W tym czasie również Oakeshott publikuje swoje pierwsze poważne pismo traktujące o Hobbesie ${ }^{5}$ oraz dwie recenzje książki Straussa ${ }^{6}$, przy czym jedna z nich wchodzi na stałe do kanonu ważniejszych wczesnych pism Oakeshotta ${ }^{7}$. Recenzja ta wraz z wprowadzeniem do powojennego, oksfordzkiego wydania Lewiatana (1946), z obszernym esejem The Moral Life in the Writings of Thomas Hobbes (1960) oraz z esejem recenzyjnym książki The Politics of Motion: the World of Thomas Hobbes Thomasa Spragensa (1974) tworzy zrąb najważniejszych pism Oakeshotta dotyczących postaci i myśli Hobbesa .

Bez wątpienia jednak nie tylko liczba tekstów poświęconych autorowi Lewiatana świadczy o znaczeniu, jakie jego doktryna wywarła na drogę intelektualną Oakeshotta. Śledząc biografię autora słynnej krytyki racjonalizmu w polityce, nie sposób nie zauważyć, że zainteresowanie pismami Hobbesa, datowane na lata 30. XX wieku, zbiega się u niego z głębszym zainteresowaniem filozofią polityczną jako ważną dziedziną rozważań naukowych ${ }^{9}$. Choć część interpretatorów Oakeshotta wydaje się zanadto uwypuklać domniemaną przełomowość tego okresu dla rozwoju jego myśli ${ }^{10}$, twierdząc choćby,

Praca ta została napisana w języku niemieckim w roku 1936, mimo że w tymże języku została opublikowana blisko trzy dekady później. Niemal od razu jednak powstał jej angielski przekład, autoryzowany przez Straussa, co - jak zauważa Oakeshott - odbiło się na wysokiej jakości tłumaczenia. L. Strauss, The Political Philosophy of Hobbes: Its Basis and Genesis, przeł. E. M. Sinclair, Oxford 1936. Por. M. Oakeshott, Leo Strauss..., s. 87.

4 C. Schmitt, Der Leviathan in der Staatslehre des Thomas Hobbes. Sinn und Fehlschlag eines Symbol, Hamburg 1938. Wyd. pol. Lewiatan w teorii państwa Thomasa Hobbesa: sens i niepowodzenie politycznego symbolu, przeł. M. Falkowski, Warszawa 2008.

Należy tu wymienić M. Oakeshott, Thomas Hobbes, „Scrutiny” 1935-1936, nr 4, s. 263-277 (zob. też: The Concept..., s. 110-121). Tekst ten jest w istocie przeglądem nowych książek, dotyczących myśli Hobbesa, które pojawiły się w latach 20. i 30. XX wieku.

6 Pierwsza z nich opublikowana w Cambridge Review stanowi w zasadzie krótką notę recenzyjną. Zob. The Political Philosophy of Hobbes, „Cambridge Review” 1936-1937, nr 58, s. 150 (zob. też: The Concept..., s. 145-146).

7 Tenże, Dr. Leo Strauss on Hobbes, „Politica” 1936-1937, nr 2, s. 364-379 (zob. też: Hobbes on Civil Association, Oxford 1975, s. 141-158). Tłum. pol. M. Oakeshott, Leo Strauss..., s. 85-98.

8 Zob. tenże, Introduction to "Leviathan", [w:] tenże, Hobbes on..., s. 1-79. Tenże, The Moral Life in the Writings of Thomas Hobbes, [w:] tenże, Hobbes on..., s. 80-140. Tenże, Logos and Telos, „Government and Opposition" 1974, vol. 9, nr 2, (zob. też: Rationalism in Politics and Other Essays, Indianapolis 1991, s. 351-359). Należy także przypomnieć, iż Oakeshott napisał również kilka mniej istotnych recenzji książek, traktujących o Hobbesie oraz opublikował krótki zapis audycji radiowej, w której mówił o Hobbesie. Zob. tenże, Leviathan: a Myth, [w:] tenże, Hobbes on..., s. 159-163.

9 S. Gerencser, The Skeptic's Oakeshott, New York 2000, s. 77-78. P. Riley, Michael Oakeshott: Philosopher of Individuality, „The Review of Politics” 1992, nr 54, s. 654-655. I. Tregenza, Michael Oakeshott on Hobbes, Exeter 2003, s. 1-2.

10 Oakeshott był wyraźnie zainteresowany rzeczami politycznymi już od swych pierwszych prób naukowych. W tym miejscu wymienić należy choćby takie eseje jak Lord Acton (1922), 
że Hobbes był inspiracją, która całkowicie zastąpiła jego wczesne fascynacje idealizmem brytyjskim, to zasadne wydaje się stwierdzenie, że właśnie począwszy od tego okresu wyraźnej i szybkiej krystalizacji ulegają elementy uznawane później za fundamentalne dla jego koncepcji filozoficznych. Pomimo że sceptycyzm poznawczy i pesymizm antropologiczny są obecne u Oakeshotta od początku jego pisarstwa, to rzeczywiście swój zdecydowany, jasny i dojrzały wyraz zaczynają uzyskiwać po zainteresowaniu się myślą Hobbesa. Stają się one nie tyle kłopotliwym źródłem wątpliwości, swego rodzaju niedogodnością uniemożliwiającą sformułowanie kompleksowej i szerokiej teorii, obejmującej całość doświadczenia ludzkiego, ile ważnym i umocowanym - choć nadal głównie dlatego, że niemożliwym do uniknięcia punktem wyjścia jego teorii. Można więc skonstatować, że właśnie wraz ze zwróceniem się w stronę Lewiatana u Oakeshotta nabierają rozpędu procesy wyłonienia się zasadnicznych podstaw filozoficznych jego koncepcji oraz swoistego pogodzenia się z wczesnymi problematycznymi intuicjami badawczymi. Pytanie, w jaki sposób dokonuje się ten proces i dlaczego to właśnie Hobbes wywiera właśnie taki wpływ na młodego, obiecującego filozofa z Cambridge, wydaje się wymagać bliższej uwagi.

Podziw dla postawy i zmyślności filozoficznej Hobbesa jest u Oakeshotta niezaprzeczalny. Wszakże w swym znanym wprowadzeniu do Lewiatana stawia on Hobbesa w gronie największych umysłów filozoficznych dziejów ${ }^{11}$. Hobbes pojawia się więc pośród postaci takich jak Platon, św. Augustyn czy Hegel. Choć według Oakeshotta dzieło Hobbesa nie poddaje się w całości jednolitej interpretacji, gdyż jak przystało na myśliciela, który nie bał się poszukiwań, zmieniał on wielokroć swe zapatrywania i pisał dzieła niewolne od konfudujących sprzeczności, to Lewiatan stanowi dojrzały i najpełniejszy wyraz jego poglądów. Źródeł jego wielkości należy dopatrywać się nie tylko $\mathrm{w}$ fakcie, że stanowi on zapis i zwieńczenie wieloletnich rozmyślań i doświadczeń egzystencjalnych Hobbesa oraz próbuje aspirować do miana dzieła integralnego i zamkniętego, w spójny sposób odpowiadającego nie tylko na pytania podstawowe o istotę człowieczeństwa, naturę człowieka, jego przeznaczenie i położenie w świecie. Choć wszystkie te elementy są niezwykle ważne, to Lewiatan jest nade wszystko perłą filozofii politycznej, która w koherentny sposób próbuje łączyć istotę i kontekst, to, co stałe, ponadczasowe, uniwersalne z tym, co ulotne, historyczne, partykularne; dojrzałe fun-

The Authority of the State (1929), John Locke (1932), The New Bentham (1932) oraz szereg recenzji prac z zakresu filozofii polityki. Faktem jednak jest, że równie dużą, jeśli nie większą uwagę, w tym czasie poświęcał on religii.

11 M. Oakeshott, Introduction..., [w:] tenże, Hobbes on..., s. 7-8, 58-60. 
damenty filozoficzne z filozofią zwracającą się ku człowiekowi żyjącemu pośród innych i zasadom, jakie winny tym współżyciem rządzić ${ }^{12}$.

Swoisty, oryginalny, nowatorski, lecz przede wszystkim trafny kształt spostrzeżeń filozoficznych Hobbesa koresponduje więc z próbą stworzenia zgodnej z nimi filozofii politycznej. Sprawia to, że właściwym kontekstem dla prób interpretacji Lewiatana nie jest tylko suma warunków, w jakich był pisany, lecz jedynie podobnie wielkie dzieła filozoficzne.

\section{Hobbes czyli sceptyk}

Próba opisania filozofii politycznej Hobbesa, jak i każdego innego myśliciela politycznego, stawia przed nami nie zawsze dotrzymywany wymóg zwrócenia wytężonej uwagi na założenia intelektualne, jakie dany autor przyjmuje, a które zazwyczaj stanowią punkt wyjścia dla jego koncepcji politycznych. W wypadku interpretacji Hobbesa dokonanej przez Oakeshotta stawiają one w polu zainteresowania problem, który - jak się wydaje - stał się również kluczową kwestią jego własnych rozważań ${ }^{13}$.

Problemem tym jest próba praktycznego ogarnięcia sceptycyzmu filozoficznego, rozumianego jako poznawcza ograniczoność człowieka i niemożność sformułowania przez niego adekwatnych stwierdzeń o otaczającym nas świecie. Owa poznawcza niemoc implikuje bowiem pokusę wycofania się, a może nawet zwątpienie w możliwość sformułowania jakiejkolwiek filozofii politycznej. Siła sceptycyzmu danego myśliciela może więc okazać się burzycielska również dla jego własnych projektów politycznych, społecznych czy etycznych. Hobbes jako jeden z nielicznych wydaje się zaś konsekwentnie podejmować starania rozwiązania tego problemu, problem ten jest zaś także ważnym dylematem Oakeshotta. Ów, przynajmniej częściowo wspólny związek inspiracji i doświadczeń, wyjaśnia zainteresowanie, jakim autor Racjonalizmu w polityce obdarza Hobbesa. Jednak zarówno z uwagi na wysoką wartość interpretacyjną analiz pism Hobbesa napisanych przez Oakeshotta, jak i z powodu szczególnej wartości, jaką przedstawiają one dla zrozumienia jego własnych teorii filozoficznych, intelektualny związek tych dwóch angielskich myślicieli domaga się bliższej uwagi.

Według rozumienia zaproponowanego przez Oakeshotta podstawą sceptycyzmu poznawczego Hobbesa jest niezbyt optymistyczna wizja człowieka, jaką nakreśla w swoich pismach ${ }^{14}$. Istota ludzka nie posiada szczególnie rozwiniętych zdolności czy możliwości, które zasadniczo wyróżniałyby ją

\footnotetext{
Tamże, s. 3-8.

S. Gerencser, The Skeptic's..., s. 90-97.

M. Oakeshott, Introduction..., [w:] tenże, Hobbes on..., s. 36-39.
} 
ze świata przyrody. Człowiek, podobnie jak inne zwierzęta, jest przede wszystkim istotą doświadczającą . Doświadczenie będące jego głównym instrumentem poznawczym sytuuje się w jego wypadku jednak na nieco wyższym poziomie. Mimowolnymi i mechanicznymi rezultatami doświadczenia ludzkiego są bowiem pamięć i wyobraźnia. Konkretne doznania zmysłowe, składające się na doświadczenie są więc zapisywane, zaś świadomość ich istnienia sprawia, że człowiek jest zdolny spojrzeć na nie z zewnątrz. Człowiek wyposażony jest zatem w zdolność introspekcji ${ }^{16}$.

Warunkiem samoświadomości człowieka i zaawansowanej artykulacji własnych doświadczeń jest istnienie języka ${ }^{17}$. Prócz możliwości komunikowania własnych myśli w interakcji z innymi, pozostaje on narzędziem wewnętrznej komunikacji, który umożliwia człowiekowi samouświadomienie sobie własnych odczuć. Język na pozór jest także narzędziem nadawania nazw przedmiotom i zjawiskom w świecie. Zdaniem Oakeshotta jest on jednak w rzeczywistości dla Hobbesa narzędziem, który inicjuje proces retrospektywnego określania obrazów doznań zmysłowych pozostających w ludzkiej pamięci i świadomości ${ }^{18}$. W rzeczywistości więc człowiek za pomocą języka nie nazywa tego, co rzeczywiste, lecz to, co subiektywnie zarejestrowane. Człowiek jedynie sytuuje pewne obiekty we własnym świecie, niekoniecznie określając ich rzeczywiste położenie ${ }^{19}$.

Nadawanie nazw obrazom zmysłowym jest warunkiem koniecznym wszelkiego rozumowania. Język nie tylko nazywa to, co ostatecznie ulotne w doświadczeniu człowieka (pamięć nie jest wszak absolutna), ale umożliwia pracę rozumu, który operuje na określonym, utrwalonym i zdefiniowanym materiale. Jedynie na danych wyabstrahowanych z doświadczenia ludzkiego poprzez język możliwe jest dokonywanie racjonalnych analiz: tworzenie definicji i znaczeń czy formułowanie twierdzeń i argumentów. Sam język jednak, pomimo że umożliwia podjęcie jakiegokolwiek rozumowania, poszukującego wiedzy ogólnej, możliwości prawdy lub nonsensu, sam w sobie jest ograniczeniem takiego działania. Rozum u Hobbesa nie jest w stanie prze-

15 Tamże, s. 23.

„W celu przezwyciężenia ograniczeń doświadczenia zmysłowego i osiągnięcia rozumnej wiedzy o naszych doznaniach, nie wystarczy tylko, że będziemy je posiadali, lecz także że będziemy ich świadomi - potrzebujemy zdolności introspekcji”. Tamże.

Jeśli introspekcja ma być naturalną zdolnością człowieka, narzędzie warunkujące jej istnienie również nie może być sztuczne. Język, jako władza naturalna człowieka, spełnia ten wymóg. Zob. tamże.

„Nazwą jest dźwięk głosu ludzkiego, użyty mocą woli człowieka na to, by był znakiem, z którego pomocą można by wzbudzać w umyśle myśl, podobną do myśli minionej". T. Hobbes, Elementy filozofii, t. 1, przeł. Cz. Znamierowski, Warszawa 1956, s. 26. Por. tamże, s. 8. Zob. też M. Oakeshott, Introduction..., [w:] tenże, Hobbes on..., s. 24.

19 Por. tenże, The Moral Life in the Writings of Thomas Hobbes, [w:] tenże, Hobbes on..., s. 89-90. 
kroczyć ram zakreślonych przez język, który sprawia, że wszelkie rozumowanie - cokolwiek by się twierdziło - jest operowaniem tylko na nazwach, a nie na rzeczywistych desygnatach tychże nazw. Rozum zatem zawsze dotyka danych zapośredniczonych przez indywidualne i zróżnicowane doświadczenia każdego człowieka. Proces komunikacji umożliwia pewne uzgodnienie nazw, lecz pozostają one konwencją, u której źródła nie leży wcale wiedza o rzeczywistości, lecz arbitralne nazwanie doświadczeń. Nazwy więc nigdy nie korespondują z rzeczywistością i nie odzwierciedlają uniwersalnego porządku rzeczy, do odkrycia którego - wydawać by się mogło miałby pretendować umysł, podejmujący proces rozumowania. Ostatecznie więc nie jest on w stanie wykroczyć poza pewne ograniczenia, poza kontekst wydarzeń w ramach których nadane zostały nazwy przedmiotom zmysłowym $^{20}$.

Nie mogąc wykroczyć poza pułapkę języka, filozofia jako proces rozumowania jest więc przede wszystkim próbą poszukiwania przyczyn i skutków, które jednak nie dotyczą rzeczywistości, lecz ludzkich wyobrażeń. Tym samym jej wyniki są zawsze hipotetyczne ${ }^{21}$.

Odkrywanie prawdopodobnych przyczyn danych zdarzeń jest głównym zadaniem filozofii z dwóch powodów. Po pierwsze, tego rodzaju wiedza może wypływać tylko z pracy rozumu, nie zaś z doświadczenia. Po wtóre, skoro materiałem, na którym operuje filozofia, są efekty naszych doświadczeń, możliwe poszerzenie naszej wiedzy w drodze racjonalnych musi zakładać badanie powiązań między tymi efektami.

Filozofia próbuje więc szukać najbardziej ogólnych przyczyn danych zjawisk, lecz nigdy pierwszej przyczyny. Ich identyfikacja ma dodatkowo zawsze charakter przypuszczalny, a zatem w ramach dociekań rozumowych nie identyfikujemy rzeczywistej przyczyny, lecz tylko przyczynę możliwą lub najbardziej prawdopodobną. „Dla rozumowania przyczyna musi być «wyobrażalna», należy wykazać, że konieczność rezultatu wynika z przyczyny"22.

Filozof jest zawsze i nieuchronnie skazany na niepewność. Hobbes pisze, że „żadne rozumowanie nie może zakończyć się poznaniem bezwzględnym faktu minionego czy też przyszłego. Albowiem poznanie faktu jest

${ }^{20}$ Por. tenże, Introduction..., [w:] tenże, Hobbes on..., s. 24.

${ }^{21}$ Filozofia najczęściej poszukuje więc „hipotetycznie racjonalnej przyczyny” danych zjawisk. „Filozofia, jak widzimy, może dowodzić od określonego efektu do jego hipotetycznie racjonalnej przyczyny, bądź też od danej przyczyny do możliwego rezultatu". Tamże, s. 30. Filozofia to „przyrodzony rozum ludzkie, pilnie oglądający z lotu wszelkie rzeczy stworzone i wypowiadający twierdzenia prawdziwe o ich porządku, przyczynach i skutkach". T. Hobbes, Elementy..., s. 8.

${ }^{22}$ Tamże, s. 25. 
pierwotnie wrażeniem zmysłowym, później zaś przypomnieniem. Co się zaś tyczy poznania powiązań między faktami, które powyżej nazwałem wiedzą, to nie jest ono bezwzględne, lecz warunkowe. Nikt nie może wiedzieć na drodze rozumowania, że to lub tamto jest, było lub będzie, to znaczy - wiedzieć coś bezwzględnie, absolutnie; człowiek może wiedzieć jedynie, że jeżeli jest to, to jest i tamto; jeżeli to a to już było, to było i tamto; jeżeli to a to będzie, to będzie i tamto. Ale to jest wiedzieć warunkowo i wiedzieć nie o tym, że jedna rzecz nastąpi po drugiej, lecz że jedna nazwa jakiejś rzeczy następuje po innej nazwie tej samej rzeczy" ${ }^{23}$.

Stojąca za myślą Hobbesa idea filozofii jako rozumowania ogranicza więc znacząco zadania myślenia filozoficznego. Skoro rozumowanie to nic innego niż dociekanie przyczyn i rezultatów rzeczy, co do kształtu których nie mamy dodatkowo całkowitej pewności, to świat w zwierciadle rozumu jest jedynie uniwersum tychże niepewnych uwarunkowań i skutków, które filozof pragnie odczytać. Skoro więc „zadaniem i celem rozumowania” jest zacząć od konsekwencji i „przechodzić od jednej konsekwencji do innej”, to przecież „nie może [...] być pewności co do konkluzji ostatecznej, gdy nie ma pewności co do wszystkich tych twierdzeń i przeczeń, na których się ona opiera i z których jest wyprowadzona" ${ }^{24}$. Z tego właśnie powodu Hobbes, zdaniem Oakeshotta, ,wyłącza z obszaru filozofii namysł nad wszechświatem jako całością, rzeczami nieskończonymi, wiecznymi, przyczynami ostatecznymi oraz sprawami poznawalnymi jedynie poprzez Bożą Łaskę bądź Objawienie" ${ }^{25}$. Interpretacja Hobbesa jako twórcy filozofii będącej przykładem radykalnego sceptycyzmu i nominalizmu sprawia więc, że niemożliwe jest interpretowanie go na popularne ongiś sposoby.

Oakeshott przekonuje przeto, że Hobbes nie jest filozofem materialistycznym. Motywem jego dociekań filozoficznych nie jest stopniowe, dokonywane w kolejnych traktatach, odsłanianie materialistycznego charakteru natury, zaś w dziedzinie filozofii politycznej stworzenie koncepcji zgodnej z materialistyczno-mechanistycznym oglądem świata. Hobbes ani nie stworzył, ani nawet nie próbował stworzyć spójnego, racjonalistycznego, materialistyczno-mechanistycznego obrazu świata, by móc później weń włączyć swą filozofię obywatelską. Analizy przekonujące o zasadności takiego odczytania jego pism są niepoprawne i zwodnicze, zaś są one owocem niewłaściwych oczekiwań dotyczących tego, czym miałby być system filozoficzny. Według nich miałby on stanowić analogon projektu architektonicznego,

${ }^{23}$ T. Hobbes, Lewiatan czyli materia, forma $i$ władza państwa kościelnego i świeckiego, przeł. Cz. Znamierowski, Warszawa 2005, s. 142-143.

Tamże, s. 120 .

M. Oakeshott, Introduction..., [w:] tenże, Hobbes on..., s. 18. 
w ramach którego filozofia naturalna miałaby być fundamentem całej konstrukcji, zaś filozofia obywatelska - jej zwieńczeniem możliwie zgodnym ze stylem całości konstrukcji. Hobbes miałby być więc pierwszym filozofem, który rzeczywiście stworzył - lub, w najgorszym razie, próbował stworzyć tego rodzaju koherentny projekt ${ }^{26}$.

Tymczasem spójność projektu filozofa z Malmesbury nie polega wcale na spójności właściwej projektowi architektonicznemu, na podstawie którego miałaby być budowana każda kolejna część gmachu jego filozofii. O wewnętrznej integralności jego projektu przesądza raczej jedna idea przenikająca wszelkie jego dążenia i dociekania. Dla Hobbesa „system to nie plan czy klucz do labiryntu filozofii, lecz raczej przewodnia wskazówka, prowadząca nas niczym nić Ariadny"

Ograniczony charakter dociekań Hobbesa nie jest dla Oakeshotta wadą. Wręcz przeciwnie, to właśnie świadomość własnych ograniczeń jest dla niego miarą wielkości danego filozofa. Prawdziwie wielkie dzieła myśli ludzkiej, a zwłaszcza filozofii politycznej, wyróżnia przede wszystkim fakt rozpoznania pesymistycznej sytuacji człowieka, niedoli ludzkiego istnienia i kłopotliwego położenia, w jakim niezmiennie się on znajduje ${ }^{28}$. To dopiero daje bowiem inspirację do poszukiwania - jak wskazuje Platoński epigraf do Wprowadzenia do "Lewiatana» - nie tego, co trywialne, byle czego, ale odpowiedzi na pytanie, jak należy żyć ${ }^{29}$. Z uwagi na fakt, że Lewiatan jest prawdziwym majstersztykiem filozoficznym, jeśli chodzi o filozofię polityki, być może jedynym napisanym w języku angielskim ${ }^{30}$, prawdziwie „urzekająco integralnym dziełem sztuki ", ; mamy prawo, a nawet obowiązek również Hobbesa zaliczać do grona prawdziwie wielkich myślicieli.

\section{Fundamenty Hobbesowskiej koncepcji polityki}

W przekonaniu Oakeshotta misterność filozofii politycznej Hobbesa, jak chciałoby wielu interpretatorów, nie wynika wcale z odkrywczości wniosków, które wysuwa. Choć zaiste Hobbes zrywa z arystotelesowskotomistyczną koncepcją prawa naturalnego w filozofii politycznej, to przecież

\footnotetext{
Tamże, s. 16-17.

Tamże, s. 17.

„Charakterystyczne dla filozofów politycznych jest to, że przyjmują posępny obraz sytuacji człowieka: zmagają się z mrokiem". Tamże, s. 6. Por. tamże, s. 62-64. Oakeshott opisując pesymistyczny (swój i Hobbesowski) ogląd sytuacji człowieka, nigdy nie posługuje się silnym ontologicznie pojęciem natury ludzkiej, opisując ją w terminologii egzystencjalnej. Implicite przyznaje się tutaj do niezgody z Hobbesem.

Tamże, s. 1. Por. Platon, Państwo, 352d.

M. Oakeshott, Introduction..., [w:] tenże, Hobbes on..., s. 3.

Tenże, O postępowaniu człowieka, Warszawa 2008, s. 283.
} 
nie ustanawia nowego początku w zakresie filozoficznych rozważań o życiu zbiorowym. Według autora Racjonalizmu w polityce wspomniane całkowite zerwanie i nowy początek nie byłyby zresztą nawet możliwe, zaś sam XVIIwieczny filozof w rzeczywistości jedynie z odwagą ożywia i rozwija pewne nurty obecne w refleksji nad polityką już od czasów starożytności ${ }^{32}$. Burzycielskie nowatorstwo Hobbesa jest więc istotne, choć znacząco ograniczone.

Tym, co naprawdę budzi zainteresowanie Oakeshotta, jest raczej błyskotliwa próba połączenia określonej postawy filozoficznej, determinującej formułowanie określonych sądów o świecie, z dążeniem do stworzenia spójnej filozofii politycznej. Ujmując rzecz precyzyjniej, Hobbes podejmuje zadanie sformułowania adekwatnej filozofii politycznej na gruncie założeń nominalizmu i sceptycyzmu filozoficznego, połączonego z pesymistycznym oglądem sytuacji człowieka. Dążenie to - jak się wydaje - było również naczelnym staraniem Oakeshotta w jego aktywności intelektualnej.

Kardynalnym imperatywem, kierującym Hobbesem w jego refleksji nad polityką jest według Oakeshotta próba złagodzenia niekorzystnego położenia, w jakim znajduje się człowiek w stanie natury. Znamieniem wielkich filozofów polityki, a do takich zalicza się Hobbes, jest próba złagodzenia ludzkiej niedoli, która wynika albo z samej jego natury, albo z głęboko zakorzenionego defektu w tej naturze ${ }^{33}$. W największych dziełach filozofii politycznej „życie ludzkie [...] jawi się generalnie nie jako uczta czy nawet podróż, lecz jako niedola" ${ }^{34}$. Polityka ma więc gwarantować takie rozwiązania wspólnego życia, które zapewnią wybawienie od najbardziej dokuczliwych niedogodności kłopotliwego położenia istoty ludzkiej. Choć różne koncepcje filozoficzno-polityczne różnią się zarówno jeśli chodzi o szczegóły dotyczące opisu sytuacji, jak i nie są zgodne co do możliwości człowieka oraz sposobu, w jaki może on poprawić sytuacje, to żadnej z nich nie można oskarżyć o popadnięcie w grzech intelektualnej pychy, który skłaniałby do nadmiernej ufności w moc filozofii, polityki i człowieka. Stąd też „każde arcydzieło filozofii politycznej wypływa z nowej wizji ludzkiej niedoli, każde jest refleksem wybawienia lub propozycją remedium" ${ }^{35}$.

Wspólne największym projektom filozoficzno-politycznym pesymistyczne odczytanie sytuacji człowieka w świecie jest więc udziałem także Hobbesa. W wypadku filozofa z Malmesbury człowiek jest istotą, jak zostało

\footnotetext{
32 Jako inspirację dla Hobbesa Oakeshott wielokrotnie wskazuje Epikura, teologię politycznę judaizmu, rzymską koncepcję lex oraz zapożyczenia augustyńskie. M. Oakeshott, Introduction..., [w:] tenże, Hobbes on..., s. 61-62.

Tamże, s. 62-63.

Tamże, s. 24.

Tamże.
} 
wspomniane wcześniej, która jest ofiarą swojego własnego solipsyzmu. Jest ona zamknięta w świecie własnych wyobrażeń na temat doświadczeń zmysłowych, z których wywodzą się także motywy jej działań, określone żądze i niechęci. Te pierwsze są więc zgodne ze zjawiskami, które sprzyjają ludzkiej witalności, drugie są jej zaś przeciwne. Są więc one powiązane $\mathrm{z}$ wolą życia człowieka oraz niechęcią wobec śmierci, która wyznacza kres ludzkiej świadomości.

Cele ludzkich dążeń zostają wyznaczone przez pamięć i wyobraźnię, gdyż oznaczają rzeczy zachowane w świadomości jako sprzyjające dobrobytowi jednostki. Nie są one jednak rzeczami o niewyczerpanym charakterze, stąd też wiąże się z nimi rzeczywistość nieuniknionej rywalizacji. Rywalizacja ta sprawia, że zdobywanie kolejnych dóbr nie jest celem głównym, staje się nim raczej ostateczne panowanie i sprawowanie kontroli nad otoczeniem, w którym one się znajdują.

Szczęście, które - mogłoby się wydawać - leży u kresu każdej zwycięskiej rywalizacji, w rzeczywistości nie wyznacza wcale jej krańca. Jest ono jedynie „stałym powodzeniem w osiąganiu tych rzeczy, jakich człowiek pragnie w różnych chwilach, to znaczy stałe prosperowanie" ${ }^{, 36}$. Człowiek zaś nie przestaje pożądać nigdy, a zatem pragnienie mocy staje się nieuchronnie związane z samym życiem. Ponadto, nawet odnosząc sukces nie może być on pewien stabilności i trwałości swojej dominacji, zaś jej utrata może mieć niepowetowane skutki ${ }^{37}$.

Do walki o dobra popycha człowieka nie tylko szansa zdobycia ich i dominacji nad innymi, lecz również duma, która się z nimi nieodmiennie wiąże. Duma ta sama w sobie jest konstytutywnym elementem ludzkiej natury. Oakeshott opisując człowieka hobbesowskiego zauważa, że choć dzieli on wiele cech ze zwierzętami, to odróżnia go od nich niewyczerpane zamiłowanie, by przewyższyć innych. Rywalizacja jest nie tylko koniecznością wynikającą z prostej niewystarczalności dostępnych dóbr, lecz również następstwem przyjemności, jaką człowiek czerpie z porównywania siebie z innymi oraz bycia na czele. Szczęście jest więc zadowoleniem wynikającym z poczucia nieustannego bycia liderem, które jest następstwem uznania innych i sukcesów w osiąganiu zaspokojeń następujących po sobie pragnień. Poczucie własnej mocy oraz wiążące się z nim pierwszeństwo, chwała czy zaszczyty są największym sukcesem, jaki może osiągnąć człowiek ${ }^{38}$.

T. Hobbes, Lewiatan..., s. 141.

Por. M. Oakeshott, The Moral Life in the Writings of Thomas Hobbes, [w:] tenże, Hobbes on..., s. 88 .

Tamże, s. 86-87. 
Duma jednak, jako najgłębiej i najsilniej zakorzenione w ludzkim istnieniu uczucie człowieka, towarzyszące mu w różnych sytuacjach i okolicznościach, jest szczególnie narażona na degenerację. W tym wypadku oznacza to groźbę przekształcenia się dumy w próżność. Próżność staje się udziałem człowieka, gdy jego pragnienie wiary w swoją wyższość przekracza wszelkie miary i jest tak silne, że wierzy on w nią nawet, gdy fakty temu przeczą. Prawdziwym zagrożeniem dla dumy nie jest jednak próżność, lecz strach, będący drugim z naczelnych uczuć wyznaczających horyzont ludzkiej aktywności.

Ludzki strach nabiera u Hobbesa charakteru niemalże egzystencjalnego. Nie oznacza on wszak strachu zwierzęcego czy li tylko stanu bycia przestraszonym, lecz będąc związanym z dumą, obejmuje także trwogę wynikającą z możliwości bycia pokonanym. Każdy, kto angażuje się w rywalizację o dobra i dążenie do wyższości nad innymi, jest jednocześnie świadomy możliwości przegranej w tym wyścigu. Uczestnictwo w wyścigu po ludzkie zaszczyty wiąże się nie tylko z ewentualną przegraną, lecz także z możnością śmierci z rąk któregoś ze współuczestników tego dążenia. Śmierć z ręki innych nie jest śmiercią naturalną. Przedwcześnie i niespodziewanie zginąć z ręki innego człowieka to akt największego upokorzenia, złamanie naszych aspiracji, zniweczenie pretensji do spełnienia naszego istnienia, które wynikają z dumy. Śmierć wymierzona przez rywala to hańba, absolutny „symbol porażki człowieka" ${ }^{39}$, największe zło, jakie może go spotkać. Każdy strach jest jedynie bladym odbiciem ostatecznego przerażenia, którym jest właśnie lęk przed haniebną śmiercią z ręki innych.

Życie człowieka - w interpretacji Hobbesa dokonanej przez Oakeshotta - jest więc nieuchronnie naznaczone napięciem pomiędzy opisanymi wyżej uczuciami: dumą i strachem. „Każda z tych podstawowych namiętności rozświetla kształt drugiej, zaś razem określają ambiwalentny związek, jaki łączy człowieka z innymi"

Człowiek, tak jak jawi się w pismach Hobbesa, nie może żyć bez innych, gdyż wówczas nie mógłby potwierdzić swojej dominacji i pierwszeństwa, jego duma nie mogłaby zatem zostać zaspokojona ${ }^{41}$. Życie pośród innych jest jednak także źródłem strachu, gdyż każdy człowiek jest wrogiem drugiego, a angażując się w rywalizację z nim nie może wykluczyć możliwości klęski.

Tamże, s. 88.

40 Tamże.

${ }^{41}$ T. Hobbes, Lewiatan..., s. 204-210. Por. M. Oakeshott, Introduction..., [w:] tenże, Hobbes on..., s. $37-38$. 
Próbę wyjścia z tej niekorzystnej sytuacji paradoksalnie umożliwia język. Choć sam w sobie nie może on pretendować do roli odbicia rzeczywistości, umożliwia on komunikację, sprawiając, że ludzie mogą nie tylko jak zwierzęta wyrażać swoje uczucia, lecz również swoją wolę. Komunikacja międzyludzka nie jest tylko instynktowna i naturalna, lecz jest tworem słów umożliwiających porozumienie. Język sam w sobie jest już rodzajem pewnej umowy. Ludzie więc, w przeciwieństwie do zwierząt, nie są skazani na wyniszczającą wojnę wszystkich ze wszystkimi. W ich horyzoncie myślowym mieści się możliwość porozumienia rozumianego jako próba sztucznego złagodzenia naturalnej sytuacji wyjściowej ${ }^{42}$.

Rozum w tym wypadku nie jest jedynym warunkiem zaprowadzenia pokoju we wzajemnych stosunkach, lecz współgra raczej z uczuciami człowieka. Pomimo że perspektywa pierwszeństwa, dominacji i wynikającej $\mathrm{z}$ nich dumy wydaje się kusząca, strach przed śmiercią sprzymierzony z rozumem podpowiada inne rozwiązanie. Wszelkie panowanie i przewaga w dynamicznej sytuacji wzajemnej rywalizacji wydają się warunkowe i ulotne. Człowiek mający w danym momencie władzę nad innymi, równie łatwo może zostać jej pozbawiony. Nawet w sprzyjającym położeniu zawsze pozostaje ktoś, z kim należy się rozprawić, jak również ktoś, kto może rozprawić się z nami. Moc wyobraźni i rozumu pozwala przewidywać możliwe konsekwencje danego stanu rzeczy i tylko wzmaga jego grozę. Strach nie jest już tylko odczuwany w przypadku bezpośredniego zagrożenia ze strony innych, ale także w odniesieniu do sytuacji, które mogą prowadzić do największego zła w przyszłości ${ }^{43}$.

W tej sytuacji rozum, próbując raczej zneutralizować strach przed gwałtowną śmiercią, podpowiada, że jej warunkiem musi być trwałe ustanowienie pokoju. To właśnie pokój jest warunkiem wyjścia z chronicznego życia w strachu przed śmiercią, która okrywa człowieka niesławą ${ }^{44}$. Trwałość i stabilność pokojowych porządków nie może jednak zostać osiągnięta na drodze prostej umowy. Ludzka pycha i dążenie do dominacji zawsze mogą skłonić człowieka do złamania, nieprzystąpienia lub zniszczenia osiągniętego porozumienia. Pokój, który jest „wynikiem wzajemnego rozpoznania wspólnego wroga" ${ }^{45}$, może zostać zatem trwale osiągnięty jedynie w jeden sposób.

${ }_{42}$ „Ludzie korzystają więc z mowy jako podstawy wzajemnego zrozumienia, które kładzie podwaliny pod jakiekolwiek porozumienie, jakie można zawrzeć z innymi w dążeniu do wypełnienia swych pragnień". Tenże, The Moral Life in the Writings of Thomas Hobbes, [w:] tenże, Hobbes on..., s. 90.

43 Tamże, s. 91.

${ }^{44}$ Oakeshott pisze, że „konsekwencją naturalnych żądz jest duma i strach, "propozycją» i obietnicą, jaką składa rozum jest zaś pokój”. Tamże, s. 92.

Tamże. 
Sposobem tym jest, według Hobbesa, solidarne poddanie się sztucznie stworzonej suwerennej władzy, która kończy frenetyczny stan wojny wszystkich ze wszystkimi $^{46}$.

W ten sposób, według Oakeshotta, Hobbes częściowo rozwiązuje niedolę człowieka w stanie natury. Pozornie zaproponowane rozwiązanie jawi się jako projekt rozumu. Hobbes identyfikując warunki zachowania pokoju, często nazywa je zasadami, nakazami, regułami, prawami rozumu, w ten sposób próbując nas przekonać, że to, co jest racjonalne, jest również obowiązkowe $^{47}$. Jednocześnie podzielana przez niego koncepcja rozumu wydaje się na tyle ograniczona, że nie może wskazywać obowiązków, lecz jedynie przyczyny, środki i cele danych zjawisk. W żaden sposób nie orzeka ona o faktach, lecz o konsekwencjach. Może ona formułować racjonalne teorematy, które jednak nie powinny mieć statusu zobowiązań moralnych. W rozważaniach Hobbesa pojawia się jednak zbyt wiele śladów świadczących o rozdźwięku w tej kwestii ${ }^{48}$. Owa wewnętrzna sprzeczność jest zbyt wyraźna, by ją zignorować, więc Oakeshott proponuje odczytać ją w sposób następujący.

Według zaproponowanej przez niego interpretacji, Hobbes, tworząc swoje koncepcje, miał dwa cele. Pierwszym było stworzenie filozofii politycznej, a ściślej teorii zobowiązania obywatelskiego, zgodnej z ogólnymi założeniami jego filozofii, z jego wizją świata i człowieka. Drugim zaś ukazanie współczesnym sobie, gdzie leżą zobowiązania dobrego obywatela, tak by zapobiec zamętowi politycznemu i anarchicznym tendencjom politycznym czasów, w których żył ${ }^{49}$.

Pierwszy cel mógł być zrealizowany przez Hobbesa zupełnie samodzielnie, w relatywnym oderwaniu od aktualnych mód i prądów intelektualnych, w wypracowanym przez siebie samego wokabularzu, opisującym adekwatnie sytuację człowieka w świecie. Realizacja drugiego mogła się natomiast powieść jedynie wówczas, gdy zostałaby wyrażona w idiomie i słowniku ówczesnej myśli politycznej, ukrywającym ewentualne innowacje dotyczące rozumienia obowiązków człowieka we wspólnocie politycznej. Nietrudno dojść zatem do wniosku, że w wypadku Hobbesa oba cele musiały

\footnotetext{
T. Hobbes, Lewiatan..., s. 257-259.

M. Oakeshott, The Moral Life in the Writings of Thomas Hobbes, [w:] tenże, Hobbes on..., s. 96. Oakeshott tworzy nawet katalog wspomnianych rozdźwięków, pojawiających się w pismach Hobbesa. Zob. tamże, s. 122-124.

49 Tamże, s. 125. Por. I. Tregenza, The Life of Hobbes in the Writings of Michael Oakeshott, „History of Political Thought" 1997, vol. 28, nr 3, s. 531-556.
} 
wejść ze sobą w konflikt i to nie w sprawach marginalnych czy pobocznach, lecz w kwestiach o kapitalnym znaczeniu dla integralności każdej z nich ${ }^{50}$.

Zdaniem Oakeshotta, liczne dyskrepancje w dziele Hobbesa mogą być zatem odczytane nie jako pomyłki, lecz jako „zręczny unik”. Hobbes chcąc stworzyć teorię zgodną z własnymi fundamentami filozoficznymi, musiał odrzucić teorię prawno-naturalną. Nawet największe modyfikacje klasycznych teorii prawa naturalnego nie mogłyby zapobiec konfliktowi z założeniami koncepcyjnymi, jakie przyjął. Stąd też, według Oakeshotta, Hobbes tworzy w rzeczywistości dwie teorie. Jedna z nich miała być więc przeznaczona jedynie dla czytelników o silnych umysłach, którzy byliby w stanie przyjąć zamęt wywołany jego radykalnym sceptycyzmem i wynikającym zeń zerwaniem $z$ teorią prawno-naturalną oraz rezerwą wobec rozumu politycznego. Drugą zaś mieli być w stanie przyjąć zwykli ludzie, zaznajomieni z jej językiem, sprawiającym że jej nowatorstwo nie byłoby nadmiernie niepokojące ${ }^{51}$. Według Hobbesa więc, pospolite umysły nie są w stanie docenić faktu, że problemy polityczne są generalnie „tajemnicami”, które muszą być rozpatrywane szczerze i otwarcie jedynie pośród tych, którzy są zaznajomieni z tego rodzaju rozważaniami i pozornie obrazoburczymi wnioskami, jakie mogą z nich płynąc ${ }^{52}$.

Autentyczna filozofia polityczna Hobbesa, zgodna z jego założeniami filozoficznymi, w interpretacji Oakeshotta neguje więc jakąkolwiek sprawczą moc rozumu. Wszelkie zobowiązania moralne w jej ramach wypływają z prawa (law). Prawo zaś jest rozkazem, a jest to „rozkaz jedynie tego, którego rozkazy zwrócone są do kogoś, kto już przed tym zobowiązany był go słuchać" ${ }^{53}$. Prawodawca zaś swój autorytet uzyskuje wcześniej i to jedynie wówczas, gdy zostanie on mu dany lub uznany przez tych, którzy zobowiązują się być mu poddanym ${ }^{54}$. Poddani muszą zatem doskonale znać podmiot

M. Oakeshott, The Moral Life in the Writings of Thomas Hobbes, [w:] tenże, Hobbes on..., s. 125126.

51 W ramach tej drugiej propozycji Hobbes miał stworzyć teorię $\mathrm{w}$ terminach prawnonaturalnych, bliską interpretacji Howarda Warrendera. Zob. H. Warrender, The Political Philosophy of Hobbes. His Theory of Obligation, Oxford 1957. Zabiegi Hobbesa były jednakże w tej kwestii niewystarczające i również „oficjalna” wersja jego teorii została potępiona i skrytykowana przez jemu współczesnych. Oakeshott przytacza też w ramach kontrpropozycji wobec swojego spojrzenia na koncepcje Hobbesa również interpretację L. Straussa, którą jednak - w przeciwieństwie do Warrendera - całkowicie odrzuca. Zob. M. Oakeshott, The Moral Life in the Writings of Thomas Hobbes, [w:] tenże, Hobbes on..., s. 99-121.

Tamże, s. 126.

T. Hobbes, Lewiatan..., s. 350 .

Tamże, s. 303. 
stanowiący prawo oraz treść tego prawa. Autorytet stanowienia prawa jest wobec tego zawsze nabyty, a nigdy naturalny ${ }^{55}$.

Zobowiązania obywateli wynikają więc jedynie z prawa, stanowionego przez dobrze znaną i zaakceptowaną władzę. Rozkaz władzy dla Hobbesa nie jest zawsze wiążący, obywatele są zobowiązani go wykonać tylko wtedy, kiedy jego moc obowiązywania zostanie potwierdzona lub obalona. Testem tym zaś jest to, czy dany rozkaz jest rzeczywiście prawem we właściwym znaczeniu tego słowa.

Civitas obywateli to więc nic innego niźli sztuczny stan ludzkiej społeczności, gdzie obowiązuje powszechnie znane prawo, mające oficjalną wykładnię i stanowione przez władzę, która tę zdolność nabyła. Obligatoryjność wynika nie z faktu, że jest ono odbiciem prawa naturalnego, lecz z tego, w jaki sposób i przez kogo jest stanowione, ogłaszane i interpretowane ${ }^{56}$. U podstaw zobowiązania obywatela w civitas Hobbesa leży prawo stanowione, którego możliwość determinuje wcześniejsza zgoda ludzi znajdujących się w podobnie niekorzystnym położeniu i ustanawiających z tego powodu wspólnego suwerena.

Przyczyną osiągnięcia porozumienia, które ustanawia władzę i daje jej określone prerogatywy, zgodnie $\mathrm{z}$ antropologicznymi założeniami Hobbesa jest strach przed śmiercią. Strach ten zostaje przekształcony w racjonalne dążenie do pokoju, które nie jest jednak obowiązkiem, lecz jedynie możliwością, z której człowiek może skorzystać. Tylko taki sposób interpretacji Hobbesa jest możliwy do pogodzenia $\mathrm{z}$ jego własnymi założeniami dotyczącymi kształtu świata i natury człowieka.

Podsumowując, Oakeshott uważa, że Hobbes swoją teorią jako pierwszy dokonuje połączenia radykalnie sceptycznych założeń filozoficznych ze stabilną filozofią polityczną. Wskazuje on, że rozum ludzki może być w tym obszarze doradcą ludzkich działań, lecz nie może być ich przewodnikiem. Albowiem „płomień uczuć nigdy nie oświeca «rozumu», lecz go oślepia" "57. Rozum więc jedynie sugeruje i wskazuje, nigdy zaś nie wydaje rozkazów. Nagrodą za uznanie innych jako równych sobie, dotrzymanie obietnic, powstrzymanie się od pogardy i nienawiści oraz wszelkich działań, mających na celu zgnębienie i przewyższenie innych jest wyzwolenie się od ciągłego strachu i niepokoju ludzkiego istnienia, zinstytucjonalizowane w ramach civitas $^{58}$.

\footnotetext{
55

M. Oakeshott, Logos and Telos, [w:] tenże, Rationalism..., s. 358-359.

T. Hobbes, Lewiatan..., s. 356-362.

Tamże, s. 275. Por. T. H. Miller, Oakeshott's Hobbes and the Fear of Political Rationalism, „Political Theory" 2001, vol. 29, nr 6, s. 806-832.

M. Oakeshott, The Moral Life in the Writings of Thomas Hobbes, [w:] tenże, Hobbes on..., s. 127.
} 
Paradoksalnie więc, w interpretacji Oakeshotta, Hobbes okazuje się być filozofem wolności i indywidualizmu ${ }^{59}$. Ostateczną instancją przesądzającą o harmonijnym życiu człowieka we wspólnocie jest bowiem ludzka wola, która pozwala Hobbesowi niejako wykrawać przestrzeń wolności z uścisku naturalnych ludzkich namiętności oraz niedoskonałości rozumu. Czyni on to, by uniwersalne racjonalne wskazania umysłu nie oznaczały wspólnego celu dla wszystkich. Poszukując zaś jedynie minimalnych warunków ludzkiego pokoju, próbuje pozostawić jak najszerszy margines swobody dla swobodnego, ludzkiego działania.

M A R C I P OLAK OW S K I

59 W kwestii obrony Hobbesa przed zarzutem bycia filozofem moralności mieszczańskiej i teoretykiem postępowania prostaczków zob. tamże, s. 127-133. Por. L. Strauss, The Political Philosophy of Hobbes..., J. A. Boyd, The Lion and the Ox: Oakeshott's Engagement with Leo Strauss on Hobbes, „History of Political Thought” 2008, vol. 29, nr 4, s. 690-716. 


\section{Abstract}

Studies of Michael Oakeshott's intellectual legacy stressed the importance of Thomas Hobbes to Oakeshott. Many interpreters of his writings argued that Hobbes' thought reflected Oakeshott's own philosophical interests. The principal aim of this article is the reflection concerning fundamental affinity of both authors' philosophical projects.

According to this I try to consider Hobbes' philosophical nominalism and skepticism, which induces the philosopher to treat reason with reserve. The recommendations of reason are always hypothethical and may never be treated as obligatory. They only indicate causes and outcomes of human actions, as well as natural phenomena. Reason can only provide us with conditional knowledge about consequences, not the absolute one concerning facts. This conception of reason forms the basis of Oakeshott's conception of philosophy as reasoning.

On this ground Hobbes also creates his political philosophy. He builds foundations of his project based on will instead of reason. The notion of will refers to primary human passions in the state of nature: pride and fear. The tension between them induce individuals to subject themselves to artificially created sovereign authority. This act is not a precept of reason, but it is rather dictated by moral prudence. 